\title{
Measuring the Burden of the Corporate Income Tax under Imperfect Competition*
}

\author{
Li Liu ${ }^{\dagger}$ and Rosanne Altshuler ${ }^{\ddagger}$
}

This version: November 10, 2011

\begin{abstract}
We model and estimate the incidence of the corporate income tax under imperfect competition. Identification comes from variation in effective marginal tax rates in the United States across industries and time. Our empirical results suggest that labor bears a significant portion of the burden of the corporate income tax. In addition, we find that the elasticity of wages with respect to the corporate marginal effective tax rate increases with industry concentration. Over all industries, our estimates suggest that a one dollar increase in corporate tax revenue decreases wages by around 60 cents.
\end{abstract}

JEL Classifications: H22, H25, H31

Keywords: Tax incidence, Wage determination, Corporate income tax, Market structure

${ }^{*}$ We are grateful to Hilary Sigman for her insightful and helpful comments. We would also like to thank Steve Bond, Colin Campbell, Michael P. Devereux, Clemens Fuest, William Gentry, Benjamin Harris, Roger Klein, Mark Killingsworth, Jack Mintz, and participants at the 2009 Summer School in Public Economics at University of Barcelona, the 2011 RES Annual Congress, the 2011 EEA-ESEM annual Congress, the 2011 IIPF conference, and workshops at Rutgers University and Oxford University for helpful comments. An earlier version of this paper was circulated with the title "Passing It On: The Incidence of the Corporate Income Tax under Imperfect Competition." Liu acknowledges financial support from the ESRC (Grant No RES -060-25-0033). All remaining errors are, of course, our own.

${ }^{\dagger}$ Centre for Business Taxation, University of Oxford, Park End Street, Oxford, OX1 1HP, UK; li.liu@sbs.ox.ac.uk.

${ }^{\ddagger}$ Department of Economics, Rutgers University, 75 Hamilton Street, New Brunswick, NJ, 08901, United States; altshule@rci.rutgers.edu. 


\section{Introduction}

Over the past two decades, most OECD countries have lowered their corporate statutory tax rates. An important yet open question is who benefits from corporate tax reforms. While the methodology for assigning the burden of changes in the personal income tax is straightforward - the individual who actually pays the tax is typically assumed to bear the burden of the tax - assigning the burden of the corporate income tax has proven to be a difficult and controversial undertaking. In the United States, the government agencies that produce distributional analyses of tax reforms use different assumptions when it comes to distributing the burden of the corporate income tax. The staff of the Joint Committee on Taxation does not distribute the corporate income tax citing uncertainty over who actually bears the burden of the tax. At the same time, the published estimates of the Congressional Budget Office and U.S. Treasury Department assign the entire burden of the corporate tax to capital owners in proportion to their share of aggregate capital income. This incidence assumption is consistent with the results from the seminal study of Harberger (1962).

As is well-known, the Harberger study assumed a closed-economy, fixed factors of production, perfect competition, and full factor mobility across sectors. Since Harberger's original analysis, public finance economists have considered how relaxing different assumptions of the model will change his finding that the corporate tax is likely borne by all owners of capital. ${ }^{1}$ For example, once we allow for an open economy with international capital mobility, domestic owners of capital may be able to escape the tax by moving capital abroad and, as a result, domestic labor may bear a substantial burden of the corporate income tax. While researchers have built and simulated theoretical models that relax many of the assumptions of the Harberger analysis (including Harberger (1995, 2006)), there have been relatively few attempts to econometrically estimate who bears the burden of the corporate income tax.

A series of recent papers present estimates of the incidence of the corporate tax (see Arulampalam, Devereux and Maffini (2010), Desai, Foley and Hines (2007), Felix (2007) and Hassett and Mathur (2010)). Since statutory corporate tax rates do not change often within a country, these studies exploit cross-country variation to identify the impact of corporate taxes on wages. These models implicitly assume that policy makers do not react

\footnotetext{
${ }^{1}$ See Fullerton and Metcalf (2002) for an excellent review of extensions of the Harberger model.
} 
to corporate tax rate changes in the countries they compete with to attract internationally mobile capital. However, if countries engage in tax competition then corporate tax rates will be endogenous. ${ }^{2}$ Taking tax competition into account could lead to different conclusions regarding the incidence of the corporate income tax. Not accounting for the endogeneity of corporate tax rates is one weakness of the recent work. Empirical work with cross-country data may also suffer from omitted variable bias and measurement error (if variables used in the analysis are not measured consistently across countries).

Researchers have also used variation in state corporate tax rates to explore the impact of corporate taxes on wages (see Gyourko and Tracy (1989), Felix (2009), Felix and Hines (2009), and Carroll and Prante (2010)). But these studies have the same problem described above. If states compete over corporate tax rates, then the tax rates in the estimated equations are endogenous responses of a tax setting game and the standard OLS estimates will be biased and inconsistent. ${ }^{3}$ Further, the use of formulary apportionment by the states to assess corporate tax liabilities makes it difficult to measure the appropriate corporate tax rate for multijurisdictional firms.

We take a new approach to measuring the burden of the corporate tax. We recognize that the tax burden on a marginal investment project depends on the asset mix of the project. Since industries use different asset mixes they will face different effective marginal tax rates. We use variation in effective marginal tax rates across industries and across time in the U.S. to estimate the incidence of the corporate income tax. This approach avoids the problems of measurement error and omitted variable error that may plague the cross-country studies. Further, limiting the analysis to one country removes the estimation problems associated with tax competition that arise in the cross-country and cross-state analyses.

The extant empirical work implicitly assumes that the corporate sector is perfectly competitive. But market structures vary across industries. The presence of strategic interaction and any resulting economic rents may have implications for incidence analysis. Corporate economic rents will arise if firms reduce output below the competitive level. As Auerbach

\footnotetext{
${ }^{2}$ The tax competition literature (see, for example, Altshuler and Goodspeed (2002), Altshuler and Grubert (2004), Winner (2005), and Devereux, Lockwood and Redoano (2008)) has provided extensive empirical evidence of strategic interaction among national governments over corporate tax rates.

${ }^{3}$ Recent evidence on strategic competition among the US states in tax rates includes Besley and Rosen (1998), Esteller-More and Sole-Olle (2001), Rork (2003), and Devereux, Lockwood and Redoano (2007).
} 
(2006) points out, a tax in an industry with restricted output due to imperfect competition will be more distortionary than one in a competitive industry since it will worsen the original distortion to output. Whether tax shifting is exacerbated depends on parameters of the economy. Our empirical approach allows us to estimate the extent to which the incidence of the corporate tax varies across industry market structure.

We use the general equilibrium model presented in Davidson and Martin (1985) to show that the elasticity of wages with respect to the corporate income tax rate may increase or decrease with the industry concentration level. We use data on individual U.S. workers matched with industry-level effective marginal tax rates and industry concentration ratios. (The industry concentration ratio proxies for the extent of imperfect competition in an industry the more concentrated the industry, the less competition each firm in the industry faces). We find a statistically significant and negative relationship between wage rates and industry effective marginal corporate tax rates. Further, our estimates suggest that the presence and extent of imperfect competition matters for analyzing the incidence of the corporate income tax. A one percent increase in the concentration ratio increases the elasticity of wages to tax rates by 9.5 percent.

We also carry out the regression analysis at the industry level to account for the possibility that the relationship between wages and taxes is only relevant for the marginal worker in the labor market. Estimates from the industry-level regressions also point to industry competitiveness playing an important role in determining the impact of the corporate income tax on wages. Both the individual- and industry-level estimates indicate that the mean elasticity of wages with respect to the industry marginal effective corporate tax rate is around -0.03 .

We translate our estimated wage elasticity into a labor share of the corporate income tax and find that the burden borne by labor of a one dollar increase in the corporate tax liability is about 60 cents. The lower bound of the labor share of the tax burden is 42 cents in our most conservative confidence interval. The estimated labor share of the tax burden is in line with the general equilibrium simulation results in Harberger (2006) but somewhat smaller than that in Randolph (2006).

The remainder of this paper proceeds as follows. In section 2 we briefly review empirical studies of the incidence of corporate income tax. In section 3 we introduce the theoretical 
framework for the empirical work and in section 4 we describe the data and present our econometric specification. We discuss our results and various econometric issues in section 5. In the final section we draw conclusions from our analysis. We provide a full derivation of our theoretical prediction as well as the industry concordance we developed to construct the dataset in the appendix.

\section{Empirical Studies of the Incidence of the}

\section{Corporate Income Tax}

Several recent empirical studies have estimated the effect of the corporate income tax on wages using cross-country data. ${ }^{4}$ Arulampalam, Devereux and Maffini (2010) consider the possibility that corporations shift income taxes to workers through the wage bargaining process. They measure the effect of corporate income taxes paid by firms (as opposed to corporate tax rates) on employee compensation using data on more than 500,000 firms in nine European countries over the period 1996 to 2003. Conditional on value-added per employee, a one dollar increase in the tax bill tends to reduce the median real wage by 49 cents. A related study by Felix and Hines (2009) using data from the year 2000 evaluates the effect of U.S. state corporate income taxes on union wages and finds that a ten percent lower state tax rate is associated with a 3.6 percent higher union wage premium. Their results suggest that union workers see a 54 cent decrease in wages for every one dollar increase in the corporate tax bill. It is important to note that these studies do not measure general equilibrium effects of the corporate tax on wages but rather the impact of the tax on the outcome of the worker and firm bargain over economic rents.

A series of studies have attempted to provide direct evidence of the general equilibrium effect of the corporate income tax on wages using cross-country data. Hassett and Mathur (2010) find that wages are highly responsive to changes in the corporate tax rate using aggregate wage and tax data within the manufacturing sector for 72 countries between 1981

\footnotetext{
${ }^{4}$ See Gravelle and Hungerford (2008), Gentry (2007), and Harris (2009) for critical reviews of empirical studies of corporate tax incidence.
} 
and 2002. The estimated elasticity of wages with respect to corporate income tax rates ranges from 0.4 to 0.6 across different specifications, indicating that a one dollar increase in tax revenue leads to a three to four dollar decrease in the real wage. As Gravelle and Hungerford (2008) point out, the large magnitude and significance of this elasticity is sensitive to the use of alternative exchange rates and time intervals. In addition, by including a measure of value-added per worker as a control variable, the identified tax coefficient fails to capture the effects of the corporate tax on wages through changes in value-added (Arulampalam, Devereux and Maffini, 2010).

Felix (2007) uses aggregate data on wages of workers at different skill levels from 19 OECD countries over the period 1979 to 2000 and estimates that a one percentage point increase in the top statutory corporate tax rate decreases annual wages by 0.7 percent. She finds no difference in the extent to which the tax is shifted to labor at different skill levels. Desai, Foley and Hines (2007) use data from US multinational firms operating in 50 countries between 1989 and 2004 to jointly estimate the relative share of the corporate tax borne by labor and capital. Constraining the portion of the total tax burden borne by capital and labor together to be one, they find that labor bears between 45 to 75 percent of the incidence of the corporate income tax.

While some have disputed the findings of these studies (see, for example, Gravelle and Hungerford (2008)), this growing body of empirical work does provide suggestive evidence that labor bears a large burden of the corporate tax. However, as discussed in the introduction, much of this work uses either cross-country or cross-state data without correcting for the possible endogeneity of corporate tax rates due to tax competition. In addition, the extant literature implicitly assumes that all firms operate in perfectly competitive markets. We consider imperfect competition in the next section and estimate the impact of corporate taxes on wages in a setting in which changes in other countries tax rates should have no impact on our estimated coefficients. 


\section{Theoretical Background}

Following Harberger (1962), we discuss the general equilibrium incidence effects of the corporate income tax in the simplest setting: an economy with corporate and noncorporate sectors producing separate goods with two fixed factors of production, capital and labor. Both factors of production are mobile across sectors and the corporate income tax is modeled as an additional tax on the returns to capital in the corporate sector.

A source-based tax on the return to corporate capital affects the equilibrium return to capital and labor through two channels: the output effect and the factor substitution effect. The output effect arises because the tax drives up the price of goods in the corporate sector. As demand for the corporate sector good decreases in response to the price increase, capital and labor will be released from the corporate sector. The factor substitution effect arises because in response to the tax, corporate good producers attempt to substitute labor for capital driving down the return to capital relative to labor. How the reallocation of capital and labor across sectors affects the relative returns to factors in equilibrium depends on the initial allocations of capital and labor in the corporate and non-corporate sectors, the degree to which firms in the corporate and non-corporate sectors can substitute labor for capital, and the elasticities of demand for corporate and non-corporate output. With calibrated factor shares and input/output substitution elasticities that are reasonable for the U.S. economy, Harberger (1962) finds that capital income bears approximately the full burden of the corporate tax.

Further work including Mutti and Grubert (1985), Harberger (1995, 2006), Gravelle and Smetters (2006), and Randolph (2006) examines the incidence of corporate income tax in an open economy in which capital can move across countries in response to changes in factor returns. ${ }^{5}$ As in the original Harberger model, the corporate sector is assumed to be characterized by perfect competition. The conclusions of the open economy general equilibrium models are straightforward: if it is feasible and profitable for capital to avoid a tax by shifting to other sectors (and abroad in an open economy model), then the burden will fall primarily on labor, assuming labor is immobile. The extent to which a shift is feasible

\footnotetext{
${ }^{5}$ See Gravelle (2010) for a review of results from general equilibrium tax incidence models of the corporate income tax.
} 
and profitable depends on a variety of assumptions.

The assumption of perfect competition fails to characterize the structure of some U.S. industries. Davidson and Martin (1985) (hereafter DM) capture the strategic effects of imperfect competition on tax incidence in a two-sector general equilibrium model. ${ }^{6}$ We use their model to motivate our empirical study of the extent to which the corporate income taxes are passed to labor through reductions in wages under imperfect competition. We leave the full derivation of the model to the Appendix and briefly discuss the economic intuition in this section.

The economy consists of a competitive (noncorporate) and an imperfectly competitive (corporate) sector. The corporate sector has a small number of firms. The corporate group plays a repeated game in which each firm produces constrained quantities of a single good under constant cost. Constrained production maximizes joint corporate profits subject to no cheating. At a given point of time, if any firm produces higher output, every firm will revert permanently to the lower Nash output level. Each firm therefore compares the current gain from a higher output level to the present value of profit loss by permanently producing at a lower output level. The present value of the profit loss due to producing at the lower level is discounted using the return to capital.

The corporate tax has the usual output and factor substitution effects. There is also another route by which the equilibrium return to factors may be affected, however. The corporate tax decreases the net return to capital and this rate of return is used to discount the value of the loss due to deviating from the constrained output level. A fall in the discount rate increases the present value of the loss in profits from diverting to a higher output level. This additional effect of the corporate tax works in the same direction as the output effect magnifying the decrease in the return to labor (capital) when the corporate sector is labor (capital) intensive. As a result, the change in relative factor prices due to the corporate tax is larger (smaller) as the corporate sector is more capital (labor) intensive.

In the appendix, we show that the elasticity of the wage with respect to the corporate income tax rate increases as the number of firms in the corporate sector decreases if the corporate sector is capital intensive. The result is ambiguous if the corporate sector is labor

\footnotetext{
${ }^{6}$ See Dixit and Stiglitz (1977) and Atkinson and Stiglitz (1980) for partial equilibrium analyses of the incidence of corporate tax under imperfect competition.
} 
intensive, however. The sensitivity of wages to changes in the corporate income tax may increase or decrease as the number of firms in an industry decreases. In the next section we present a model that allows us to estimate the impact of the corporate income tax on wages and test whether any impact changes with industry concentration.

\section{Research Design and Data}

We model the natural logarithm of weekly wages for individual $i$ in industry $j$ in year $t, w_{i j t}$, as a function of the corporate tax rate $\left(T_{j t}\right)$, the market concentration ratio $\left(C R_{j t}\right)$, the interaction between the tax rate and the concentration ratio, as well as individual characteristics $\left(X_{i j}\right)$ and industry and time-specific fixed effects $\left(c_{j}\right.$ and $\left.\eta_{t}\right)$ :

$$
\ln w_{i j t}=X_{i j} \alpha+\beta_{1} \ln T_{j t}+\beta_{2} \ln C R_{j t}+\beta_{3}\left(\ln T_{j t} \times \ln C R_{j t}\right)+c_{j}+\eta_{t}+\varepsilon_{i j t} .
$$

The main parameters of interest are $\beta_{1}$ and $\beta_{3}$. The value of $\beta_{1}$ measures the extent to which the corporate tax effects wages, while the value of $\beta_{3}$ indicates whether industry concentration influences how taxes impact wages.

Our measure of the industry corporate tax is the industry-level effective marginal corporate tax. This summary tax measure is a function of effective marginal tax rates on the assets employed in an industry. The asset-level effective marginal tax rates, discussed further in the next section, are calculated taking statutory tax rates as well as tax incentives such as depreciation allowances and investment tax credits into account. The statutory rate applies to all assets and changes across our sample period. Depreciation allowances and the investment tax credit vary both across capital asset types and across time. For each industry and year, we calculate a weighted average marginal effective tax rate based on the asset mix in the industry in the year being examined.

The industry-level effective marginal tax rate captures how the tax incentive to invest in the average investment project differs across industries and is well-suited for our incidence analysis since our goal is to identify the effect of the corporate income tax on wages through its impact on factor reallocation across industries. Another advantage of the ef- 
fective marginal tax rate is that unobserved shocks to individual wages are unlikely to be correlated with the industry-level characteristics. Therefore, the industry-level tax and industry concentration provide plausible exogenous determinants of wages at the individual level.

\subsection{Sample Selection Issues}

Approximately one quarter of the observations in our sample (described below in section 4.2) have missing wages because the individual did not work, presenting a typical sample selection problem. The working sample is nonrandomly chosen, and the unobserved factors that determine the wage are likely to be correlated with the unobservables that influence one's decision to work. It is well known that a simple OLS regression on the working sample would yield biased and inconsistent estimates. ${ }^{7}$ To correct for the sample selection bias, we add a first-stage selection equation, in which the probability of being employed $\left(e m p l_{i}\right)$ depends on one's nonwork income $\left(i n c_{i}\right)$, education $\left(e d u c_{i}\right)$, age, marital status (married $\left._{i}\right)$, number of children younger than $5\left(\operatorname{child} 5_{i}\right)$, number of children between age 6 and 19 $\left(\operatorname{child} 20_{i}\right)$, and white noise $\left(u_{i}\right)$ :

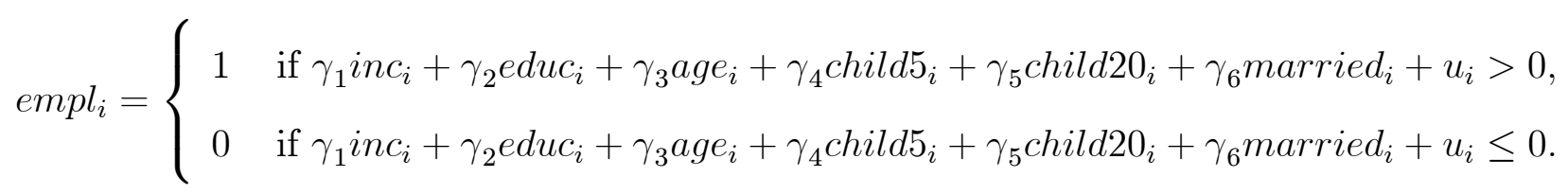

The exclusion restriction is that nonwork income should affect one's decision to work but should not impact the marginal utility from work. We measure nonwork income by aggregating net income received in the form of rents, dividends, interest, private transfers, and alimony payments. We model married women as the secondary earner of the household and include the husband's wage and salary in their nonwork income.

\footnotetext{
${ }^{7}$ See Heckman, Lochner and Todd (2006) for an excellent survey on wage estimation with correction for sample selection bias.
} 


\subsection{Data}

Effective tax rates. We use the effective marginal tax rate to capture the effect of tax policy on investment. As is well-known, the marginal effective tax rate is the percentage difference between the pre-tax and after-tax rate of return on a marginal investment project. This rate summarizes all modeled tax provisions (the statutory tax rate, present value of depreciation allowances, and investment credits) that apply to an incremental dollar of capital investment in a hypothetical project.

We calculate the effective marginal corporate tax rate for each industry by taking a weighted average of the effective marginal tax rates on all of the assets used in the industry. We obtain asset level effective tax rates $\left(E T R_{a t}\right)$ from Fullerton and Henderson (1985) and Mackie (2002). Both papers follow the Hall-and-Jorgenson cost-of-capital approach and compute the effective marginal corporate tax rates for 34 types of investment in equipment and nonresidential structures. Cross-time variation in effective tax rates comes from two sources: changes in the tax system due to the Tax Reform Act of 1986 (TRA86) and changes in macroeconomic conditions reflected in the real interest and inflation rates. ${ }^{8}$ The tax rates in Fullerton and Henderson (1985) are calculated for 1982 while those in Mackie (2002) are calculated for 1992 and 1997. Both before and after TRA86, there is variation in effective tax rates across assets as a result of differences in depreciation schedules. Before TRA86 there is additional variation across asset types due to the presence of the investment tax credit for equipment.

We use the capital flow tables provided by the Bureau of Economic Analysis of the U.S. Commerce Department to construct asset-specific weights for our industry-level marginal effective tax rates. The capital flow tables are published in the Survey of Current Business and are available approximately every five years. We use information for 1982, 1992 and 1997 since we have calculated marginal effective tax rates for assets only for these years. The tables provide information on new capital investment in equipment and structures by industry. We compute the weight for each asset $a$ in industry $j$ in year $t\left(W_{a j t}\right)$ as the value of new investment relative to total industry new investment. ${ }^{9}$ The year-specific industry

\footnotetext{
${ }^{8}$ After TRA86, there was only one major change to the corporate tax in our sample period. The Omnibus Budget Reconciliation Act of 1993 added a new fourth bracket to the corporate tax at 35 percent.

${ }^{9}$ We effectively assume that the distribution of new capital across assets is equal to the existing distribution
} 
ETR is calculated as ${ }^{10}$

$$
E T R_{j t}=\sum_{a=1}^{34} E T R_{a t} W_{a j t}
$$

Industry concentration ratios. We use Economic Census data on industry revenue to calculate concentration ratios for each industry. The market concentration ratio is the total revenue of the four largest firms relative to total industry revenue.

Table 1 provides summary statistics for the industry marginal effective tax rates and concentration ratios. There is substantial variation in both variables across industries and time. The mean effective tax rate increased from about 20 percent in 1982 to 32 percent in 1992 and 1997. Meanwhile, the average market concentration ratio decreased from about 33 percent in 1982 to approximately 24 percent in the 1990s.

Individual characteristics. Our individual-level data is from IPUMS-CPS, an integrated dataset of the randomly-sampled March Current Population Survey (CPS). The CPS data provide individual-level information on wages and industry affiliation. We restrict our sample to full-time private sector workers between ages 17 and 65 , and exclude students and those working in the armed forces. The final sample contains 287,111 individuals.

Table 2 reports information on the demographic and socioeconomic characteristics of the sample. We impute years of schooling from nine categories of educational attainment. ${ }^{11} \mathrm{We}$ compute work experience (Exper) as the difference between age and the years of schooling minus six $\left(\right.$ Exper $\left._{i}=a g e_{i}-s_{i}-6\right)$. Socioeconomic characteristics include annual nonwork income, an indicator for being married, age, number of children younger than 5 years old, and number of children between the ages of 6 and 20. Table 2 also reports average weekly wages for workers. As discussed in section 4.1, we model the decision to work as a function of the socioeconomic variables. The wage process is determined by the individual characteristics described above (with the exclusion of nonwork income), as well as the industry

of capital across assets. This gives us an average marginal effective tax rate for each industry.

${ }^{10}$ The effective tax rate calculation for each industry parallels that of Gruber and Rauh (2007) and Dwenger and Steiner (2008).

${ }^{11}$ We impute the number of years of schooling, $s_{i}$, from the following categorical scheme of educational attainment: $1=$ 'None or preschool' (0 years); $2={ }^{\prime} 1-4$ grades' (2.5 years); $3={ }^{\prime} 5-8$ ' (6.5 years); $4=$ '9' (9 years); $5={ }^{\prime} 10$ ' (10 years); $6={ }^{\prime} 11$ ' (11 years); $7=$ '12' (12 years); $8=$ '1-3 years of college' (14 years); $9=$ ' $4+$ years of college' (16 years). Education is measured as the highest level reported in CPS. 
characteristics including the effective marginal corporate tax rate, concentration ratio, and the interaction term between the tax rate and concentration ratio.

Industry Comparability: NAICS, SIC and Census Code. We use data from three major sources: the BEA Capital Flow tables, the Economic Census, and the IPUMS-CPS. Each uses a different industry classification system and these systems changed over the sample period. As a result, we needed to develop a unified industry classification. The detailed matching procedure is described in the appendix. Table A1 provides descriptions of the 41 matching industries. While this industry classification is not as refined as the BEA's 3-digit SICs, it contains more industries than typically used in the effective tax rate literature. (see, for example, Gravelle (1994), Mackie (2002) and Gruber and Rauh (2007)).

\section{Empirical Results and Discussion}

\subsection{Individual-level Evidence}

Table 3 reports the estimated effects of effective marginal tax rates and concentration ratios on the weekly wage. Table 4 summarizes the estimation results from the first-stage selection equation. We use the same first-stage Probit selection model for all specifications. At the second stage, we regress wages on the effective marginal corporate tax rates and concentration ratios, controlling for individual characteristics (years of education, experience, experiencesquared, number of children younger than 5, number of children between 6 and 20, marital status, and region dummies). We estimate the wage equation with year and industry fixed effects to account for unobserved industry heterogeneity. The estimated tax coefficient in column 1 is negative and statistically different from zero. Wages are higher for workers in industries with lower effective marginal tax rates.

The remaining columns of Table 3 take imperfect competition into account. As shown in column 2, the magnitude of the estimated tax coefficient decreases slightly once we control for industry concentration (although the difference between the tax coefficients in columns 1 and 2 is statistically insignificant). Columns 3 and 4 present estimates of the full model including the interaction between the tax rate and concentration ratio from the two-stage 
Heckman regression and maximum likelihood estimation. The coefficient of the interaction term is negative and highly significant. Combining the coefficient estimate on the interaction term with the negative tax coefficient suggests that the elasticity of wage with respect to the tax rate increases with the industry concentration level. This result suggests that for a uniform increase in the effective tax rates in U.S. economy, workers in the concentrated industries bear a larger share of the corporate tax burden.

\subsection{Industry-level Evidence}

Labor economists have documented a wide dispersion in wages across industries for workers with similar socioeconomic characteristics. These industry wage premiums are highly persistent over time (Krueger and Summers, 1988; Dickens and Katz, 1987a,b), and there is no evidence of arbitrage activities in employment movement (Dickie and Gerking, 1998; Helwege, 1992). These findings suggest that labor market conditions may vary at the industry level in equilibrium, generating industry-specific market-clearing wage rates. If this is the case, the relevant observation for the incidence analysis will be the industry wage rate and our individual-level data will overstate the true number of degrees of freedom.

In this section we repeat our analysis at the industry level by constructing a pseudopanel of average wage rates and worker characteristics. ${ }^{12}$ We run a fixed-effect regression with the pseudo-panel and report the estimation results in columns 1 and 2 of Table 5 . Both the estimated tax coefficient and the interaction term remain negative and statistically significant. The magnitude of these coefficients are similar to the individual-level estimates. ${ }^{13}$ The regression in column 2 includes additional industry fixed effects and yields a smaller tax coefficient than that in column 1. It is important to control for unobserved industry heterogeneity in this setting because part of the variation in the tax rates comes from the different asset mix across industries. But the choice of asset mix does not only respond to tax incentives; it can also be determined by the unobserved industry-specific factors (Liu, 2011). If the unobserved industry heterogeneity is correlated with the effective marginal tax

\footnotetext{
${ }^{12}$ By averaging across workers in an industry, we assume that the average worker is the relevant observation.

${ }^{13}$ Several individual characteristic estimates including the education coefficient lose their significance in the industry-level regression due to the limited variation in averages of individual characteristics across industries.
} 
rates, estimates of the tax coefficient would be biased and inconsistent.

To address the potential aggregation bias from using industry averages, we run a twostep regression where we regress the individual wage against all individual socioeconomic characteristics with correction for sample selection bias. We then regress the industry-level residuals on tax rates, the concentration ratio, and the interaction term:

$$
\ln \operatorname{resid}_{j t}=\mu+\beta_{1} \ln T_{j t}+\beta_{2} \ln C R_{j t}+\beta_{3} \ln T_{j t} \times \ln C R_{j t}+c_{j}+\eta_{t}+\varepsilon_{j t}
$$

where resid $_{j t}$ is the industry average of residuals $\widehat{\varepsilon}_{i j t}$ from the first-step wage regression:

$$
\ln w_{i j t}=\mu+\alpha X_{i j t}+\varepsilon_{i j t}
$$

The estimation results are summarized in columns 3 and 4 of Table 5 . The second-stage estimates of the tax rate and the interaction term are negative and statistically significant once we control for unobserved industry heterogeneity. The magnitude of the estimates is smaller than those from the industry-average regression but confirm our results that the elasticity of wage with respect to the tax rates decreases with industry competitiveness.

\subsection{Testing the Endogeneity of Concentration Ratio}

We use the concentration ratio to measure industry competitiveness, which in turn may be affected by the previous decisions and profits of firms in the industry. For example, in searching for higher profits, incumbent firms can strategically increase the entry barrier and limit the number of firms in an industry. If part of the wage payment comes from economic rents and hence correlates with the concentration level, the coefficient on the OLS estimate of the concentration ratio will be biased. The coefficient on the OLS estimate of the interaction between concentration ratio and the tax rate will also be biased. We therefore should test

for the endogeneity of industry competitiveness using variables that are exogenous to the wage determination process.

Intensive advertising as well as research and development (R\&D) can result in higher 
industry entry barriers. Following Symeonidis (2008), we derive two dummy variables based on advertising and R\&D intensity. We extract data from the Annual Compustat North America Industrial Files and use advertising and R\&D expense relative to industry sales to measure advertising and $\mathrm{R} \& \mathrm{D}$ intensities. We construct a dummy variable $A D V$ which equals 0 for industries with advertising-sales ratio lower than two percent and 1 otherwise. The dummy variable $R D$ is constructed in a similar fashion. It equals 0 for industries with R\&D-sales ratios lower than two percent and 1 otherwise. While the levels of advertising and R\&D intensities are endogenous, whether they are above or below the two percent cutoff point is determined by exogenous industry characteristics (Symeonidis, 2008). For industries below the cutoff point, either advertising or R\&D is not an important strategic variable. Most industries stay consistently either below or above the two percent level across all of the years in the sample period.

The natural market size can also affect the industry concentration level due to the nature of products and associated transportation costs. Some industries such as perishable food or beverage production are geographically less mobile due to transportation costs and therefore confined to a smaller market size than footloose industries. We estimate the annual industrylevel transportation costs following Ederington, Levinson and Minier (2005). Specifically, we regress transportation costs on a vector of industry dummies for each sample year, controlling for distance and distance squared for the 15 largest exporting partners of the United States. We use the industry fixed-effects coefficient as the measure of transportation costs. Since the transportation cost data is only available for the non-service industries, we include a dummy (TMISS) taking on a value of 1 if no information on the transportation cost is available. ${ }^{14}$

We perform the regression-based Durbin-Wu-Hausman test by regressing the concentration ratio on the effective tax rates, the advertising and $\mathrm{R} \& \mathrm{D}$ dummies, and transportation costs:

$$
\ln C R_{j t}=\mu+\delta_{11} A D V_{j t}+\delta_{21} R D_{j t}+\delta_{31} T R A N S_{j t}+\delta_{41} T M I S S_{j t}+c_{j}+\eta_{t}+v_{1 i j t} .
$$

\footnotetext{
${ }^{14}$ The fixed-effects coefficient is set to zero for industries with no information on transport cost. Both the industry fixed-effects coefficient and the dummy denoting a missing value for the transport cost are included in the regression.
} 
We interact the tax rate with the fitted value of the concentration ratio ${\widehat{\ln C R_{j t}}}_{\text {from equation }}$ (2) to instrument the endogenous interaction term (Wooldridge, 2008, p. 118-120 and 235237):

$$
\begin{aligned}
\ln E T R_{j t} * \ln C R_{j t}= & \mu+\delta_{12} A D V_{j t}+\delta_{22} R D_{j t}+\delta_{32} T R A N S_{j t}+\delta_{42} T M I S S_{j t} \\
& +\delta_{5} \ln E T R_{j t} * \widehat{\ln C R_{j t}}+c_{j}+\eta_{t}+v_{2 i j t} .
\end{aligned}
$$

Under the maintained assumption that all the explanatory variables in equation (2) and (3) are exogenous, the structural error $\varepsilon_{i j t}$ in equation (1) should not be correlated with the reduced form error $v_{1 i j t}$ and $v_{2 i j t}{ }^{15}$ To test this hypothesis, we run an augmented industrylevel two-step regression with $\widehat{v}_{1 i j t}$ and $\widehat{v}_{2 i j t}$ as additional regressors and jointly test whether the two coefficients on the residuals equal zero. The resulting large $p$-value (0.50) indicates that we cannot reject exogeneity of either the concentration ratio or the interaction term. ${ }^{16}$

\subsection{Labor Share of the Corporate Income Tax}

The marginal effect of changes in the effective marginal corporate tax on wages varies across the distribution of the concentration ratio. At any given concentration level, the elasticity of wage with respect to the corporate tax rate is

$$
\frac{\partial \ln w_{j t}}{\partial \ln T_{j t}}=\beta_{1}+\beta_{3} \ln C R_{j t} .
$$

Table 6 summarizes the wage elasticity at different quartiles of concentration ratio using both the individual-level and industry-level estimates. Overall, accounting for the effect of concentration ratio, the average elasticity of wages with respect to the marginal effective corporate tax rate is -0.028 using the individual-level estimates from column (3) of table 4 and -0.038 using the industry-level estimates from column (2) and (4) of table 5. Computed

\footnotetext{
${ }^{15}$ This method is equivalent to regressing the interaction term on the exogenous variables as well as a long list of additional nonlinear functions of the exogenous variables.

${ }^{16}$ Results of the DWH test are robust to alternate cutoff points including 1.5 percent and 3 percent for the advertising and R\&D intensities.
} 
at different quartiles of concentration ratio, the wage elasticity increases with the concentration ratio. The wage elasticity at the fourth quartile is at least four times larger than the elasticity at the second quartile, suggesting more shifting of corporate income taxes in the more concentrated industries.

To assess the incidence of corporate income tax, we calculate the impact of a one dollar increase in corporate tax liabilities on total wages. In 1997 (the last year of our sample), total U.S. corporate income tax revenue was $\$ 182.29$ billion. A ten percentage increase of the effective marginal rate would raise the corporate tax revenue by $\$ 18.23$ billion providing the tax base remains constant. Total U.S. wages and salaries in 1997 were $\$ 3,874$ billion. ${ }^{17}$ Assuming no adjustment in total employment, a 0.28 percent drop in the wage rate (our column 1 estimate from Table 6 ) would decrease total compensation by $\$ 10.96$ billion. Hence, the burden borne by labor of a one dollar increase in corporate tax liability is around $\$ 0.60$. The 95 percent confidence interval for the average elasticity suggests that the labor share of the tax burden lies between 59 and 61 percent of corporate tax revenue.

Labor's share of the corporate tax burden is approximately 80 percent of corporate tax revenue if we use the industry-level estimates. For every dollar increase in the corporate tax revenue, the associated 95 percent confidence interval for the decrease in wage rate is between $\$ 0.42$ and $\$ 1.19$ using the industry-average estimates and between $\$ 0.62$ and $\$ 1.00$ using the two-step estimates. These estimates suggest that labor bears a substantial share of the tax burden. If capital and labor equally bear the burden of the tax, the share of the burden that labor bears will be in proportion to its share of income, which is around two-thirds in the United States. This rule-of-thumb estimate is close to our most conservative labor share of tax burden imputed from individual-level results, suggesting that labor possibly bears more of the corporate tax burden than its share of income.

\footnotetext{
${ }^{17}$ Annual wage estimates from National Occupational Employment and Wage Estimates published by Bureau of Labor Statstics.
} 


\section{Conclusion}

We measure the responsiveness of wages to changes in corporate income taxes. We use variation in industry-level tax changes to identify the impact of corporate income taxes on wage rates within the United States, allowing differences in industry concentration to affect the incidence analysis. We find that corporate marginal effective taxes rates have a negative effect on workers' wages. In addition, our results suggest that the shifting of corporate taxes to wages intensifies with the degree of industry concentration.

Our findings suggest that labor shares a significant part of the burden of corporate income taxes. A direct calculation of the mean marginal effect of the corporate income tax from our estimates suggests that a ten percentage increase in the tax rate would decrease the average wage rate by $0.28-0.38$ percent. Labor shares at least 42 percent of the burden of the corporate tax and possibly more. The average labor share of the corporate tax burden is around $60-80$ percent.

One important caveat is that, due to the limitation of our data structure, we are unable to study the dynamic effects of corporate tax rates. While the theory of the tax incidence suggests that changes of factor input occur instantaneously with changes in the tax rates, it is likely that the adjustment process plays out over many periods and therefore, the short-run incidence may differ from the long-run incidence of the corporate taxes. In future research we plan to investigate the dynamics of corporate tax shifting.

In line with other empirical work on the incidence of corporate income tax, we focus on the effect of corporate tax rates on wage rates. A more complete analysis would also investigate the effect of the tax on employment. Distinguishing between the quantity and price effects of corporate taxes remains an important topic for further research. 


\section{References}

Altshuler, Rosanne, and Harry Grubert. 2004. "Taxpayer Responses to Competitive Tax Policies and Tax Policy Responses to Competitive Taxpayers: Recent Evidence." Tax Notes International, 34(13): 1349-1362.

Altshuler, Rosanne, and Timothy Goodspeed. 2002. "Follow the Leader? Evidence on European and U.S. Tax Competition." Rutgers University, Department of Economics Departmental Working Papers 200226.

Arulampalam, Wiji, Michael P. Devereux, and Giorgia Maffini. 2010. "The Direct Incidence of Corporate Income Tax on Wages." Institute for the Study of Labor (IZA) IZA Discussion Papers 5293.

Atkinson, A. B., and Joseph E. Stiglitz. 1980. Lectures on Public Economics. London: McGraw-Hill Book Co.

Auerbach, Alan J. 2006. "Who Bears the Corporate Tax? A Review of What We Know." In Tax Policy and the Economy, Volume 20. , ed. James M. Poterba. Cambridge, MA: MIT Press.

Besley, Timothy J., and Harvey S. Rosen. 1998. "Vertical Externalities in Tax Setting: Evidence from Gasoline and Cigarettes." Journal of Public Economics, 70(3): 383-398.

Carroll, Robert, and Gerald Prante. 2010. "Corporate Taxes and Wages: Evidence from the 50 States." Tax Foundation Working Paper 8.

Davidson, Carl, and Lawrence W Martin. 1985. "General Equilibrium Tax Incidence under Imperfect Competition: A Quantity-setting Supergame Analysis." Journal of Political Economy, 93(6): 1212-23.

Desai, Mihir A., Fritz Foley, and James Hines. 2007. "Labor and Capital Shares of the Corporate Tax Burden: International Evidence." ITPF and Urban-Brookings Tax Policy Center Conference of "Who Pays the Corporate Tax in an Open Economy?" mimeo. 
Devereux, Michael P., Ben Lockwood, and Michela Redoano. 2007. "Horizontal and Vertical Indirect Tax Competition: Theory and Some Evidence from the USA." Journal of Public Economics, 91(3-4): 451-479.

Devereux, Michael P., Ben Lockwood, and Michela Redoano. 2008. "Do Countries Compete over Corporate Tax Rates?" Journal of Public Economics, 92(5-6): 1210 - 1235.

Dickens, William T., and Lawrence F. Katz. 1987a. "Inter-Industry Wage Differences and Theories of Wage Determination." In Unemployment and the Structure of Labor Markets. , ed. Kevin Lang and Jonathon S. Leonard, 48-89. New York and Oxford: Basil Blackwell.

Dickens, William T., and Lawrence F. Katz. 1987b. "Interindustry Wage Differences and Industry Characteristics." Working Paper 2014, Cambridge, MA: National Bureau of Economic Research.

Dickie, Mark, and Shelby Gerking. 1998. "Interregional Wage Disparities, Relocation Costs, and Labor Mobility in Canada." Journal of Regional Science, 38(1): 61-87.

Dixit, Avinash K, and Joseph E Stiglitz. 1977. "Monopolistic Competition and Optimum Product Diversity." American Economic Review, 67(3): 297-308.

Dwenger, Nadja, and Viktor Steiner. 2008. "Effective Profit Taxation and the Elasticity of the Corporate Income Tax Base: Evidence from German Corporate Tax Return Data." DIW Berlin, German Institute for Economic Research Discussion Papers 829.

Ederington, Josh, Arik Levinson, and Jenny Minier. 2005. "Footloose and PollutionFree." The Review of Economics and Statistics, 87(1): 92-99.

Esteller-More, Alex, and Albert Sole-Olle. 2001. "Vertical Income Tax Externalities and Fiscal Interdependence: Evidence from the US." Regional Science and Urban Economics, 31(2-3): 247-272.

Felix, R. Alison. 2007. "Passing the Burden: Corporate Tax Incidence in Open Economies." Federal Reserve Bank of Kansas City Regional Research Working Paper RRWP 07-01. 
Felix, R. Alison. 2009. "Do State Corporate Income Taxes Reduce Wages?" Federal Reserve Bank of Kansas City Economic Review Q II.

Felix, R. Alison, and James Hines. 2009. "Corporate Taxes and Union Wages in the United States." National Bureau of Economic Research Working Paper 15263.

Fullerton, Don, and Gilbert E. Metcalf. 2002. "Tax Incidence." , ed. Alan J. Auerbach and Martin Feldstein Vol. 4 of Handbook of Public Economics, Chapter 26, 1787-1872. Elsevier.

Fullerton, Don, and Yolanda Kodrzycki Henderson. 1985. "Long-run Effects of the Accelerated Cost Recovery System." The Review of Economics and Statistics, 67(3): 36372.

Gentry, William M. 2007. "A Review of the Evidence on the Incidence of the Corporate Income Tax." US Department of the Treasury Office of Tax Analysis OTA Paper 101.

Gravelle, Jane. 1994. The Economic Effects of Taxing Capital Income. Cambridge, MA: The MIT Press.

Gravelle, Jane G., and Kent A. Smetters. 2006. "Does the Open Economy Assumption Really Mean That Labor Bears the Burden of a Capital Income Tax?" The B.E. Journal of Economic Analysis and Policy, 6(1).

Gravelle, Jane G., and Thomas L. Hungerford. 2008. "Corporate Tax Reform: Issues for Congress." Congressional Research Service CRS Report for Congress.

Gravelle, Jennifer C. 2010. "Corporate Tax Incidence: Review of General Equilibrium Estimates and Analysis." Congressional Budget Office Working Paper 2010-03.

Gruber, Jonathan, and Joshua Rauh. 2007. "How Elastic Is the Corporate Income Tax Base?" In Taxing Corporate Income in the 21st Century. , ed. Alan J. Auerbach, James R. Hines and Joel Slemrod. Cambridge University Press.

Gyourko, Joseph, and Joseph Tracy. 1989. "The Importance of Local Fiscal Conditions in Analyzing Local Labor Markets." Journal of Political Economy, 97(5): 1208-31. 
Harberger, Arnold C. 1962. "The Incidence of the Corporation Income Tax." Journal of Political Economy, 70: 215.

Harberger, Arnold C. 1995. "The ABCs of Corporation Tax Incidence: Insights into the Open-Economy Case." In Tax Policy and Economic Growth. 51-73. Washington, D.C.: American Council for Capital Formation Center for Policy Research.

Harberger, Arnold C. 2006. "Corporation Tax Incidence: Reflections on what is Known, Unknown, and Unknowable." In Fundamental Tax Reform: Issues, Choices, and Implications., ed. John W. Diamond and George R. Zodrow. Cambridge: MIT Press.

Harris, Benjamin H. 2009. "Corporate Tax Incidence and Its Implications for Progressivity." Urban Institute and Brookings Institution Tax Policy Centre Working Paper, Washington DC.

Hassett, Kevin A., and Aparna Mathur. 2010. "Spatial Tax Competition and Domestic Wages." American Enterprise Institute for Public Policy Research Working Paper 185.

Heckman, James J., Lance J. Lochner, and Petra E. Todd. 2006. "Earnings Functions, Rates of Return and Treatment Effects: The Mincer Equation and Beyond." , ed. Erik Hanushek and F. Welch Vol. 1 of Handbook of the Economics of Education, Chapter 7, 307-458. Elsevier.

Helwege, Jean. 1992. "Sectoral Shifts and Interindustry Wage Differentials." Journal of Labor Economics, 10(1): 55-84.

Krueger, Alan B, and Lawrence H Summers. 1988. "Efficiency Wages and the Interindustry Wage Structure." Econometrica, 56(2): 259-93.

Liu, Li. 2011. "Do Taxes Distort Corporations' Investment Choices? Evidence From Industry-Level Data." Ph.D. Dissertation, Rutgers University.

Mackie, James B. 2002. "Unfinished Business of the 1986 Tax Reform Act: An Effective Tax Rate Analysis of Current Issues in the Taxation of Capital Income." National Tax Journal, LV(2): 293-337. 
Mutti, John, and Harry Grubert. 1985. "The taxation of capital income in an open economy: the importance of resident-nonresident tax treatment." Journal of Public Economics, 27(3): 291-309.

Randolph, William C. 2006. "International Burdens of the Corporate Income Tax." Congressional Budget Office Working Paper Series 2006-09, Washington DC.

Rork, Jonathan C. 2003. "Coveting thy Neighbor's Taxation." National Tax Journal, 56: $775-787$.

Symeonidis, George. 2008. "The Effect of Competition on Wages and Productivity: Evidence from the United Kingdom." The Review of Economics and Statistics, 90(1): 134-146.

Winner, Hannes. 2005. "Has Tax Competition Emerged in OECD Countries? Evidence from Panel Data." International Tax and Public Finance, 12: 667-687.

Wooldridge, Jeffrey M. 2008. Econometric Analysis of Cross Section and Panel Data, 2nd Edition. The MIT Press. 


\section{A Theory}

In this section we first summarize the Davidson and Martin (1985) (DM) model of the incidence of the corporate income tax under imperfect competition and then derive a comparative static result that describes how the degree of imperfect competition affects the incidence of the corporate income tax. The comparative static result presented in the last section suggests that the wage elasticity with respect to the corporate tax is an increasing function of the industry concentration level.

\section{A.1 Partial Equilibrium in the Corporate Sector}

Suppose that there are $I$ industries in the economy. Each industry has a corporate (imperfectly competitive) sector and a noncorporate (competitive) sector. The corporate sector has $N$ firms. The corporate group plays a repeated game in which each firm produces constrained quantities of a single good $X$ under constant cost. Constrained production maximizes the joint profit in the corporate sector subject to no cheating. If any firm cheats by producing a higher quantity at time $t$, every firm will revert permanently to the Nash output level. Each firm compares the current gain from cheating to the present value of profit loss by permanently producing at a lower output level. The net gains from cheating (Z) are

$$
Z=\left(\pi^{c h}-\pi^{c}\right)-\frac{1}{r}\left(\pi^{c}-\pi^{n}\right)
$$

where $\pi^{c h}$ denotes the profit from cheating, $\pi^{c}$ the profit per firm under constrained production, $\pi^{n}$ the profit per firm in the static Nash equilibrium, and $r$ the price of capital, i.e. the interest rate.

Let $Q_{c}$ denote the constrained production quantity per firm. The corporate sector chooses $Q_{c}$ from the set of sustainable outputs defined as $Q \equiv\left\{Q_{c}: Z \leq 0, Q_{c} \geq 0\right\}$. The profit of the corporate group is:

$$
\pi^{c}=Q_{c}\left[P\left(X_{c}, \omega\right)-c\right]
$$

where $P(\cdot, \omega)$ is the inverse demand function for good $X,{ }^{18} c$ the constant unit cost of

\footnotetext{
${ }^{18} P(\cdot, \omega)$ is assumed to be single peaked and twice differentiable to guarantee a well-defined maximization
} 
production and $\omega$ is a vector of shift parameters. The static Nash profit is:

$$
\pi^{n}=\max _{Q_{n}} Q_{n}\left\{P\left[(N-1) \bar{Q}+Q_{n}, \omega\right]-c\right\}
$$

for which DM assume the existence of a symmetric solution. Lastly, the profit from cheating is:

$$
\pi^{c h}=\max _{Q_{c h}} Q_{c h}\left\{P\left[(N-1) Q_{c}+Q_{c h}, \omega\right]-c\right\}
$$

Focusing on the special case in which the representative consumer has a utility function of the form:

$$
U(X, Y)=(1-\alpha) \ln Y+\alpha \ln X
$$

the inverse demand curve for $X$ is:

$$
P_{x}=\frac{\alpha M}{X}
$$

where $M$ is the total income, and $\alpha$ is the budget share of good $X$.

Substituting equation (8) into profit functions (6) and (7), DM solve for $\pi^{n}$ and $\pi^{c h}$. Further substituting $\pi^{n}, \pi^{c h}$ and $\pi^{c}$ into equation (4) and setting $Z\left(Q_{c}\right)=0$, DM solve for $Q_{c}$ :

$$
Q_{c}=\frac{\alpha M(N-1)(r N-1)^{2}}{c N^{2}(r N+1)^{2}}
$$

The inverse demand curve for $X$ now becomes

$$
P_{x}=\frac{N(r N+1)^{2}}{(N-1)(r N-1)^{2}} c .
$$

In general, the inverse demand function under cooperation is a function of the basic parameters in the model:

$$
P_{x}=P_{x}(\omega, c, r)
$$

In the perfect competition case, $r$ represents the net return to capital and affects the output price by increasing the cost of production $c$. Under imperfect competition, $r$ enters (11) as problem. 
a separate argument. This separate effect captures the impact of the price of capital on the pricing decision of the corporate group. Specifically,

$$
\frac{d P_{x}}{d r}=\frac{\partial P_{x}}{\partial c}\left(\frac{\partial c}{\partial r}\right)+\frac{\partial P_{x}}{\partial r}
$$

The first term in (12) is positive since an increase in $r$ increases the cost of capital. The second term in (12) is negative since an increase in $r$ represents a greater inducement to increase output, which leads to a lower price. It captures the additional effect of $r$ on prices under imperfect competition. The overall impact of $r$ on the price depends on the relative magnitude of these two effects.

\section{A.2 The Corporate Sector in General Equilibrium}

Now consider the corporate sector as part of the standard two-sector general equilibrium model. There are two goods in each industry, $X$ and $Y$. Perfect competition prevails in the $Y$ sector, while the behavior of firms in the corporate sector $(X)$ is characterized as above. Both sectors employ capital $(K)$ and labor $(L)$ both of which are fully mobile between sectors. All firms are price takers in the capital market.

Following standard notation, $q_{j}$ is the gross-of-tax output price of good $j, c_{j}$ the unit cost function for good $j, w$ and $r$ the net returns to labor and capital, respectively, $T_{j}$ one plus the ad valorem output tax on good $j, T_{i j}$ one plus the partial factor tax on input $i$ used in the production of good $j$, and $M$ the aggregate income.

Assuming $Z\left(Q_{c}\right)>0$, the gross price in the corporate sector is given by

$$
q_{x}=q_{x}\left(q_{y}, M, c_{x} T_{x}, r\right)
$$

Assuming perfect competition in the $Y$ sector, the price of $Y$ equals the marginal cost of production:

$$
q_{y}=c_{y}\left(w T_{L y}, r T_{K y}\right) T_{y} .
$$


Aggregate demands for the two products are

$$
\begin{aligned}
& X=X\left(q_{x}, q_{y}, M\right), \\
& Y=Y\left(q_{x}, q_{y}, M\right)
\end{aligned}
$$

and all income is spent in equilibrium

$$
M=q_{x} X+q_{y} Y .
$$

We also assume fixed supplies of labor $\left(L_{0}\right)$ and capital $\left(K_{0}\right)$ and full employment:

$$
\begin{aligned}
c_{L x} X+c_{L y} Y & =L_{0} \\
c_{K x} X+c_{K y} Y & =K_{0}
\end{aligned}
$$

where $c_{i j}$ are the partial derivatives of the $j$ th unit cost function with respect to the $i$ th factor and represent the $i$ th input requirement per unit of output of the $j$ th good.

For simplicity, DM choose $w$ as the numeraire and drop equation (15) from the system, leaving six equations in six unknowns. Substituting the behavior of the corporate sector characterized by equation (10) into (13) yields

$$
q_{x}=\frac{N(r N+1)^{2}}{(N-1)(r N-1)^{2}} c_{x} T_{x}
$$

Finally, differentiating (14) and (20) we get

$$
\widehat{q}_{x}-\widehat{q}_{y}=-\left(\theta^{*}+\Psi\right) \widehat{r}+\left(\widehat{T}_{x}-\widehat{T}_{y}\right)+\theta_{K x} \widehat{T}_{K x}-\theta_{K y} \widehat{T}_{K y},
$$

where the circumflex denotes proportional change, $\theta^{*}=\theta_{L x}-\theta_{K x}$ measures the value of factor intensity, and $\theta_{L j} \equiv w c_{L j} T_{j} / c_{j}$ measures labor's share in industry $j$. The second term 
$\Psi \equiv 4 r N /\left[(r N)^{2}-1\right]$ captures the effect of change in $r$ on the ability of the corporate sector to enforce its output restriction.

Differentiating and differencing the demand (15)-(16) and full-employment conditions (18)-(19) yields

$$
\begin{aligned}
\widehat{X}-\widehat{Y} & =-\left(\widehat{q}_{x}-\widehat{q}_{y}\right) \\
\lambda^{*}(\widehat{X}-\widehat{Y}) & =-\left(a_{x} \sigma_{x}+a_{y} \sigma_{y}\right) \widehat{r}-a_{x} \sigma_{x} \widehat{T}_{x}-a_{y} \sigma_{y} \widehat{T}_{y},
\end{aligned}
$$

where $\sigma_{j}>0$ the elasticity of substitution between $K$ and $L$ in the production of the $j$ th good with respect to a change in relative rental prices, $\lambda^{*} \equiv \lambda_{L x}-\lambda_{K x}$ where $\lambda_{i j} \equiv c_{i j} / i_{0}$ measures the share of factor $i$ in industry $j$, and $a_{j} \equiv \theta_{K j} \lambda_{L j}+\theta_{L j} \lambda_{K j}>0$.

Equations (21)-(23) constitute a three-equation general equilibrium model with three unknowns: $\widehat{X}-\widehat{Y}, \widehat{q}_{x}-\widehat{q}_{y}$, and $\widehat{r}$. We now consider the incidence of a capital tax $T_{K x}$ in the corporate sector.

A tax on capital in the corporate sector $T_{K x}$ decreases the net return of capital $r$. Note that $r$ has two effects on the oligopolistic sector: it allocates the fixed supply of capital between industries and measures time preference. In the latter role, the level of $r$ determines the present value of profit loss due to cheating. A fall in $r$ reduces the inducement to cheat, and allows the cartel to sustain a lower output and higher price.

In particular, by setting $\widehat{T}_{x}=\widehat{T}_{y}=\widehat{T}_{K y}=0$ in (21)-(23) and solving for the elasticities of relative outputs, prices, and factor returns, the impact of a corporate income tax is characterized by the following system of equations:

$$
\begin{aligned}
\widehat{r} D^{*} & =\left(\theta_{K x} \lambda^{*}-a_{x} \sigma_{x}\right) \widehat{T}_{K x} \\
(\widehat{X}-\widehat{Y}) D^{*} & =-\left(\theta_{K y} a_{x} \sigma_{x}+\theta_{K x} a_{y} \sigma_{y}+a_{x} \sigma_{x} \Psi\right) \widehat{T}_{K x} \\
\left(\widehat{q}_{x}-\widehat{q}_{y}\right) D^{*} & =\left(\theta_{K y} a_{x} \sigma_{x}+\theta_{K x} a_{y} \sigma_{y}+a_{x} \sigma_{x} \Psi\right) \widehat{T}_{K x}
\end{aligned}
$$

where $D^{*} \equiv a_{x} \sigma_{x}+a_{y} \sigma_{y}+\lambda^{*}\left(\theta^{*}+\Psi\right)$ and is positive for stability. ${ }^{19}$ As in the standard

\footnotetext{
${ }^{19}$ See Davidson and Martin (1985) for a detailed discussion of the stability properties.
} 
model of tax incidence, the corporate tax $T_{K x}$ induces an output effect $\theta_{K x} \lambda^{*}$ and a factor substitution effect $a_{x} \sigma_{x}$ in the right-hand side of equation (24). Recall that $\lambda^{*}=\lambda_{L x}-\lambda_{K x}$ measures the relative factor intensity in the corporate sector. If the corporate sector is labor intensive, i.e. $\lambda^{*}>0$, the output effect will increase $r / w$. On the other hand, the factor substitution effect will unambiguously decrease $r / w$. The effect of imperfect competition, $\Psi$, affects $D^{*}$ in the same direction as the sign of the measure of physical factor intensity, $\lambda^{*}$. If the corporate sector is labor intensive, imperfect competition leads to a larger $D^{*}$ and consequently a smaller elasticity.

\section{A.3 Comparative Statics with Imperfect Competition}

We are particularly interested in how the tax effect on wages varies with industry concentration. To explore this question we derive the first-order condition of factor prices with respect to the number of firms in the corporate sector. Writing out equation (24) explicitly, we have

$$
\frac{\widehat{r}}{w}=\frac{\left(\theta_{K x} \lambda^{*}-a_{x} \sigma_{x}\right)}{a_{x} \sigma_{x}+a_{y} \sigma_{y}+\lambda^{*}\left(\theta^{*}+\Psi\right)} \widehat{T}_{K x}
$$

Since percentage deviations from equilibrium equal the natural log-deviations up to first order, we have

$$
\ln w-\ln r=\frac{-\left(\theta_{K x} \lambda^{*}-a_{x} \sigma_{x}\right)}{a_{x} \sigma_{x}+a_{y} \sigma_{y}+\lambda^{*}\left(\theta^{*}+\Psi\right)} \ln T_{K x}+c,
$$

where $c=\ln w^{*}-\ln r^{*}-\ln T_{K x}^{*}$, the difference in pre-perturbation equilibrium values. ${ }^{20}$ Rearranging we get

$$
\ln w=\frac{-\left(\theta_{K x} \lambda^{*}-a_{x} \sigma_{x}\right)}{a_{x} \sigma_{x}+a_{y} \sigma_{y}+\lambda^{*}\left(\theta^{*}+\Psi\right)} \ln T_{K x}+\ln r+c .
$$

Define $\eta_{w T}$ the elasticity of wage with respect to the corporate income tax. It depends on

\footnotetext{
${ }^{20} T_{K x}^{*}=0$ before the introduction of capital tax in the $X$ sector.
} 
the basic parameters as follows:

$$
\eta_{w T} \equiv \frac{\partial \ln w}{\partial \ln T_{K x}}=\frac{-\left(\theta_{K x} \lambda^{*}-a_{x} \sigma_{x}\right)}{a_{x} \sigma_{x}+a_{y} \sigma_{y}+\lambda^{*}\left(\theta^{*}+\Psi\right)}
$$

Based on equation (30), we derive two key observations. First, $\eta_{w T}$ is negative if $\theta_{K x} \lambda^{*}-$ $a_{x} \sigma_{x}>0$, for which a necessary condition is that the corporate sector in the U.S. is labor intensive. Second, $\eta_{w T}$ depends on the degree of industry competitiveness. Specifically,

$$
\frac{\partial \eta_{w T}}{\partial N}=\frac{\left(\theta_{K x} \lambda^{*}-a_{x} \sigma_{x}\right) \lambda^{*}}{\left[a_{x} \sigma_{x}+a_{y} \sigma_{y}+\lambda^{*}\left(\theta^{*}+\Psi\right)\right]^{2}} \frac{\partial \Psi}{\partial N} .
$$

As we know that

$$
\begin{aligned}
\frac{\partial \Psi}{\partial N} & =\frac{4 r\left[(r N)^{2}-1\right]-4 r N[2(r N) \times r]}{\left[(r N)^{2}-1\right]^{2}} \\
& =\frac{-4 r-4 r^{3} N^{2}}{\left[(r N)^{2}-1\right]^{2}}<0
\end{aligned}
$$

the elasticity of wage with respect to corporate tax rate decreases with the number of firms in the corporate sector if the corporate sector is capital intensive, or alternatively, if the corporate sector is labor intensive and the output effect dominates the factor substitution effect. For a given positive difference between the output and substitution effect, a small number of firms implies a large share of joint profit for each firm, and alternatively, a smaller gain from cheating. In this case, the tax-induced change in the return to capital would imply a large profit loss from diverting to a higher output level in present value. Consequently, the additional effect of corporate tax due to imperfect competition works in the same direction as the output effect, and has the strongest impact on wages in the least competitive industries. ${ }^{21}$

\footnotetext{
${ }^{21}$ As a special case, $\partial \Psi / \partial N \rightarrow 0$ as $N \rightarrow \infty$. The wage elasticity converges to the standard prediction in a two-sector GE model.
} 


\section{B Derivation of A Consistent Industry Classification}

We collect data from three major sources: the Bureau of Economic Analysis (BEA) Capital Flows for the calculation of effective tax rates, the Economic Census for the calculation of concentration ratio, and the IPUMS-CPS for individual-level information. Each data source uses a different industry classification system. The BEA's industry groups are based on the Standard Industrial Classification (SIC) system. The Census uses SICs for market concentration data, and the IPUMS-CPS uses the Census Industrial Classification (CIC) system. Each classification also changes over time. The SIC system was entirely replaced by NAICS in year 1997. To overcome the problems due to inconsistency among classification systems, we develop a unified industry classification for the period of analysis.

\section{B.1 The Unified Industry Classification}

The first step in creating a unified industry series is to create the baseline industry categories. This baseline classification is constrained by the most aggregated classification system in the data sources, the industry groups in the 1992 BEA capital flow table. Following the industry classification of the 1992 national input-output accounts, the 1992 BEA capital flow table groups industries into 64 categories based on the 1987 SICs. Most grouping are based on the 2-digit SICs, while some are based on the 3-digit level.

We further refine this baseline classification due to cross-time matching constraint. Using a concordance between the 72 and 87 SICs, we wanted to assign the 80 industries in 1982 into the 64 groups as in the 1992 BEA data. However, while most industries are grouped at a more detailed 72 SIC level, a few are grouped at a more aggregated than their 82 counterparts ${ }^{22}$. These few exceptions require us to further aggregate industries to 41 categories based on the 2-digit 1987 SICs $^{23}$.

\footnotetext{
${ }^{22}$ For example, information is only availabe for transportation and warehousing in 1972, while in 1982 detailed information are available for each of the subcategories including railroad transportation $(40,474)$, local and interurban passenger transportation (41), trucking and warehousing (42), water transportation (44), transportation by air (45), pipeline, except natural gas (46), transporation services $(472,473,478)$.

${ }^{23}$ With the excpetion that the Transportation Equipment class is based on the 3-digit SICs.
} 


\section{B.2 Match with SICs and NAICS}

The second step is to match 72 SICs and 97 NAICs to the unified classification. For the first match, the 1987 Standard Industrial Classification manual provides a 4-digit code crosswalk between the 1972 and 1977 SICs and between the 1977 and 1987 SICs. Based on this correspondence, all the changes from 1972 to 1987 SIC industries are within the 41 categories. There are no crossover changes. The 72 SICs are directly mapped 87 SICs and the unified industry classes. For the match between 97 NAICS and 87 SICs, we use a crosswalk provided by the Census which links each 4-digit NAICS to their corresponding 4-digit 87 SICs. Although a 4-digit 1987 SIC can be assigned to multiple NAICS, this problem is minimized at 2-digit level, i.e. grouping NAICS by their 2-digit SICs. This is another advantage of our 2-digit SIC based classification system.

\section{B.3 Match with CICs}

For this match, we rely on the census' classified index of industries and occupations, which provides a crosswalk between the title of each industry and its 3-digit SICs. We assign each CIC a unified industry number by further aggregating the 3-digit SICs at 2-digit level. The 1970 CICs are based on 1967 SICs and the 1990 CICs are based on 1987 SICs. We check group comparability across time using a crosswalk provided by the 1972 and the 1987 SIC manual. All the changes from 1967 to 1987 SIC industries are within the 41 categories. There are no crossover changes. 
Table 1: Summary Statistics: Effective Tax Rate (ETR) and Concentration Ratio (CR)

\begin{tabular}{llllll}
\hline \hline & Mean & SD & Min & Max & N \\
\hline ETR & & & & & \\
Overall & 28.38 & 7.76 & 5.93 & 40.25 & 122 \\
Across year & & 3.67 & 15.01 & 37.17 & \\
Across industry & & 6.87 & 12.63 & 44.54 & \\
CR & & & & & \\
Overall & 26.51 & 18.4 & 1.88 & 91.8 & 96 \\
Across year & & 17.56 & 3.95 & 88.19 & \\
Across industry & & 5.33 & 12.21 & 39.24 & \\
& & & By Year & & \\
ETR 82 & 20.19 & 5.82 & $10.72(18)$ & $33.40(36)$ & 40 \\
ETR 92 & 32.49 & 4.78 & $7.92(35)$ & $38.67(38)$ & 41 \\
ETR 97 & 32.26 & 5.12 & $5.93(35)$ & $40.26(36)$ & 41 \\
CR 82 & 32.75 & 18.96 & $5.1(33)$ & $91.8(9)$ & 28 \\
CR 92 & 23.49 & 19.17 & $1.88(36)$ & $89.88(9)$ & 34 \\
CR 97 & 24.38 & 16.29 & $5.67(35)$ & $82.88(9)$ & 34 \\
\hline
\end{tabular}

ETR is the effective marginal tax rate and CR is the four-firm concentration ratio. Associated industry code in parentheses. For 1982, ETR is missing for "Motion Picture" industry (39). For all years, CR is missing for the following industries: Agriculture(1), Forestry and Fishing (2), Mining (4)-(6), Construction (7); Additional CR is missing in 1982 for Transportation (29), Communication (30), Electric, Gas and Sanitary Services (31), Finance and Insurance (34), Real Estate (35), and Health, Educational and Social Services (41). 
Table 2: Summary Statistics: Demographic and Socioeconomic Characteristics

\begin{tabular}{|c|c|c|}
\hline & Mean & Std. Dev \\
\hline Age & 37.87 & 13.45 \\
\hline No. Children of 0-5 years & 0.21 & 0.52 \\
\hline No. Children of 5-17 years & 0.74 & 1.10 \\
\hline \multirow[t]{2}{*}{ Married } & 0.60 & 0.49 \\
\hline & \multicolumn{2}{|c|}{ Labor market variables } \\
\hline Employment & 0.67 & 0.76 \\
\hline Unemployment & 0.07 & 0.08 \\
\hline Not in labor force & 0.26 & 0.16 \\
\hline Weeks worked & 35.79 & 21.49 \\
\hline Wage and salary income & 15165 & 21569 \\
\hline Log weekly earnings (positive values) & 5.55 & 0.91 \\
\hline \multirow[t]{2}{*}{ Nonwork income (positive values) } & 9.95 & 21.13 \\
\hline & \multicolumn{2}{|c|}{ Education variables } \\
\hline Imputed years of schooling & 12.53 & 2.87 \\
\hline Years of college $(4+)$ & 18.68 & 20.75 \\
\hline Years of college (1-3) & 22.44 & 21.75 \\
\hline 12 th grade & 36.43 & 34.28 \\
\hline 11th grade & 5.36 & 5.39 \\
\hline 10th grade & 5.65 & 5.71 \\
\hline 9th grade & 3.80 & 3.99 \\
\hline 5-8th grade & 6.02 & 6.43 \\
\hline 1-4th grade & 1.15 & 1.21 \\
\hline Non or preschool & 0.47 & 0.49 \\
\hline Sample size & \multicolumn{2}{|c|}{275,789} \\
\hline
\end{tabular}


Table 3: Individual-level Regression: Wage Equation Estimates

\begin{tabular}{|c|c|c|c|c|}
\hline & $\begin{array}{l}1) \\
2 \text {-Stage }\end{array}$ & $\begin{array}{l}\text { (2) } \\
\text { 2-Stage }\end{array}$ & $\begin{array}{l}\text { 2-Stage } \\
\text { 2-St }\end{array}$ & $\begin{array}{l}(4) \\
\text { MLE }\end{array}$ \\
\hline Ln Tax & $\begin{array}{l}-0.0724^{* * *} \\
(0.0089)\end{array}$ & $\begin{array}{l}-0.0611^{* * *} \\
(0.0163)\end{array}$ & $\begin{array}{l}-0.2384^{* * *} \\
(0.0292)\end{array}$ & $\begin{array}{l}-0.2183^{* * *} \\
(0.0269)\end{array}$ \\
\hline Ln CR & & $\begin{array}{l}0.0142^{* *} \\
(0.0069)\end{array}$ & $\begin{array}{l}-0.1056^{* * *} \\
(0.0178)\end{array}$ & $\begin{array}{l}-0.0910^{\text {*** }} \\
(0.0164)\end{array}$ \\
\hline Ln $\operatorname{Tax} *$ Ln CR & & & $\begin{array}{l}-0.1059^{* * *} \\
(0.0145)\end{array}$ & $\begin{array}{l}-0.0924^{* * *} \\
(0.0133)\end{array}$ \\
\hline Years of Education & $\begin{array}{l}0.1544^{* * *} \\
(0.0021)\end{array}$ & $\begin{array}{l}0.1602^{* * *} \\
(0.0027)\end{array}$ & $\begin{array}{l}0.1603^{* * *} \\
(0.0027)\end{array}$ & $\begin{array}{l}0.1226^{* * *} \\
(0.0015)\end{array}$ \\
\hline Experience & $\begin{array}{l}0.1076^{* * *} \\
(0.0011)\end{array}$ & $\begin{array}{l}0.1094^{* * *} \\
(0.0012)\end{array}$ & $\begin{array}{l}0.1094^{* * *} \\
(0.0012)\end{array}$ & $\begin{array}{l}0.1084^{* * *} \\
(0.0010)\end{array}$ \\
\hline Experience Squared & $\begin{array}{l}-0.0012^{* * *} \\
(0.0000)\end{array}$ & $\begin{array}{l}-0.0012^{* * *} \\
(0.0000)\end{array}$ & $\begin{array}{l}-0.0012^{* * *} \\
(0.0000)\end{array}$ & $\begin{array}{l}-0.0012^{* * *} \\
(0.0000)\end{array}$ \\
\hline Education*Experience & $\begin{array}{l}-0.0031^{* * *} \\
(0.0001)\end{array}$ & $\begin{array}{l}-0.0032^{* * *} \\
(0.0001)\end{array}$ & $\begin{array}{l}-0.0032^{* * *} \\
(0.0001)\end{array}$ & $\begin{array}{l}-0.0031^{* * *} \\
(0.0001)\end{array}$ \\
\hline Constant & $\begin{array}{l}2.3567^{* * *} \\
(0.0460)\end{array}$ & $\begin{array}{l}3.3262^{* * *} \\
(0.0722)\end{array}$ & $\begin{array}{l}2.9714^{* * *} \\
(0.1007)\end{array}$ & $\begin{array}{l}3.7390^{* * *} \\
(0.0810)\end{array}$ \\
\hline Other Individual Characteristics & $\mathrm{Y}$ & $\mathrm{Y}$ & $\mathrm{Y}$ & $\mathrm{Y}$ \\
\hline Regional Dummies & $\mathrm{Y}$ & $\mathrm{Y}$ & $\mathrm{Y}$ & $\mathrm{Y}$ \\
\hline Time and Industry Fixed Effects & $\mathrm{Y}$ & $\mathrm{Y}$ & $\mathrm{Y}$ & $\mathrm{Y}$ \\
\hline Number of Observations & 247112 & 212508 & 212508 & 212508 \\
\hline Censored Observations & 79661 & 79661 & 79661 & 79661 \\
\hline
\end{tabular}

Note: Additional individual characteristics included in the regression are number of children younger than 5, number of children between 6 and 20, and marrital status. Standard errors in parentheses. ${ }^{*}$ significant at $10 \%$; ** significant at $5 \%$; *** significant at $1 \%$. 
Table 4: Individual-level Regression: Employment Equation Estimates

\begin{tabular}{|c|c|c|c|c|}
\hline & $\begin{array}{l}(1) \\
\text { 2-Stage }\end{array}$ & $\begin{array}{l}(2) \\
\text { 2-Stage }\end{array}$ & $\begin{array}{l}(3) \\
\text { 2-Stage }\end{array}$ & $\begin{array}{l}(4) \\
\text { MLE }\end{array}$ \\
\hline Nonwork Income & $\begin{array}{l}-0.0066^{* * *} \\
(0.0002)\end{array}$ & $\begin{array}{l}-0.0053^{* * *} \\
(0.0002)\end{array}$ & $\begin{array}{l}-0.0053^{* * *} \\
(0.0002)\end{array}$ & $\begin{array}{l}-0.0041^{* * *} \\
(0.0001)\end{array}$ \\
\hline Years of Education & $\begin{array}{l}0.1202^{* * *} \\
(0.0010)\end{array}$ & $\begin{array}{l}0.1293^{* * *} \\
(0.0011)\end{array}$ & $\begin{array}{l}0.1293^{* * *} \\
(0.0011)\end{array}$ & $\begin{array}{l}0.1137^{* * *} \\
(0.0010)\end{array}$ \\
\hline Age & $\begin{array}{l}-0.0084^{* * *} \\
(0.0002)\end{array}$ & $\begin{array}{l}-0.0084^{* * *} \\
(0.0002)\end{array}$ & $\begin{array}{l}-0.0084^{* * *} \\
(0.0002)\end{array}$ & $\begin{array}{l}-0.0076^{* * *} \\
(0.0002)\end{array}$ \\
\hline \# of Children Younger than 5 & $\begin{array}{l}-0.2133^{* * *} \\
(0.0055)\end{array}$ & $\begin{array}{l}-0.2220^{* * *} \\
(0.0059)\end{array}$ & $\begin{array}{l}-0.2220^{* * *} \\
(0.0059)\end{array}$ & $\begin{array}{l}-0.2051^{* * *} \\
(0.0057)\end{array}$ \\
\hline \# of Children Between 6 and 20 & $\begin{array}{l}0.0593^{* * *} \\
(0.0027)\end{array}$ & $\begin{array}{l}0.0545^{* * *} \\
(0.0028)\end{array}$ & $\begin{array}{l}0.0545^{* * *} \\
(0.0028)\end{array}$ & $\begin{array}{l}0.0508^{* * *} \\
(0.0027)\end{array}$ \\
\hline Married & $\begin{array}{l}0.2386^{* * *} \\
(0.0067)\end{array}$ & $\begin{array}{l}0.1998 * * * \\
(0.0071)\end{array}$ & $\begin{array}{l}0.1998^{* * *} \\
(0.0071)\end{array}$ & $\begin{array}{l}0.1751^{* * *} \\
(0.0068)\end{array}$ \\
\hline Constant & $\begin{array}{l}-0.8016^{* * *} \\
(0.0145)\end{array}$ & $\begin{array}{l}-1.0347^{* * *} \\
(0.0155)\end{array}$ & $\begin{array}{l}-1.0347^{* * *} \\
(0.0155)\end{array}$ & $\begin{array}{l}-0.8956^{* * *} \\
(0.0146)\end{array}$ \\
\hline Number of Observations & 247112 & 212508 & 212508 & 212508 \\
\hline
\end{tabular}

Note: The regression model is:

empl $_{i}= \begin{cases}1 & \text { if } \gamma_{1} \text { nwinc }_{i}+\gamma_{2} e d u c_{i}+\gamma_{3} a g e_{i}+\gamma_{4} k i d s 5_{i}+\gamma_{5} k i d s 20_{i}+\gamma_{6} \text { mrst } \\ 0 & \text { if } \gamma_{1} \text { nwinc }_{i}+\gamma_{2} \text { educ }_{i}+\gamma_{3} \text { age } e_{i}+\gamma_{4} k i d s 5_{i}+\gamma_{5} k i d s 20_{i}+\gamma_{6} \text { mrst }_{i}+u_{i} \leq 0\end{cases}$

This is the first-stage equation which corrects for sample selection bias in the wage equation. Standard errors in parentheses. ${ }^{*}$ significant at $10 \%$; ${ }^{* *}$ significant at $5 \%$; *** significant at $1 \%$. 


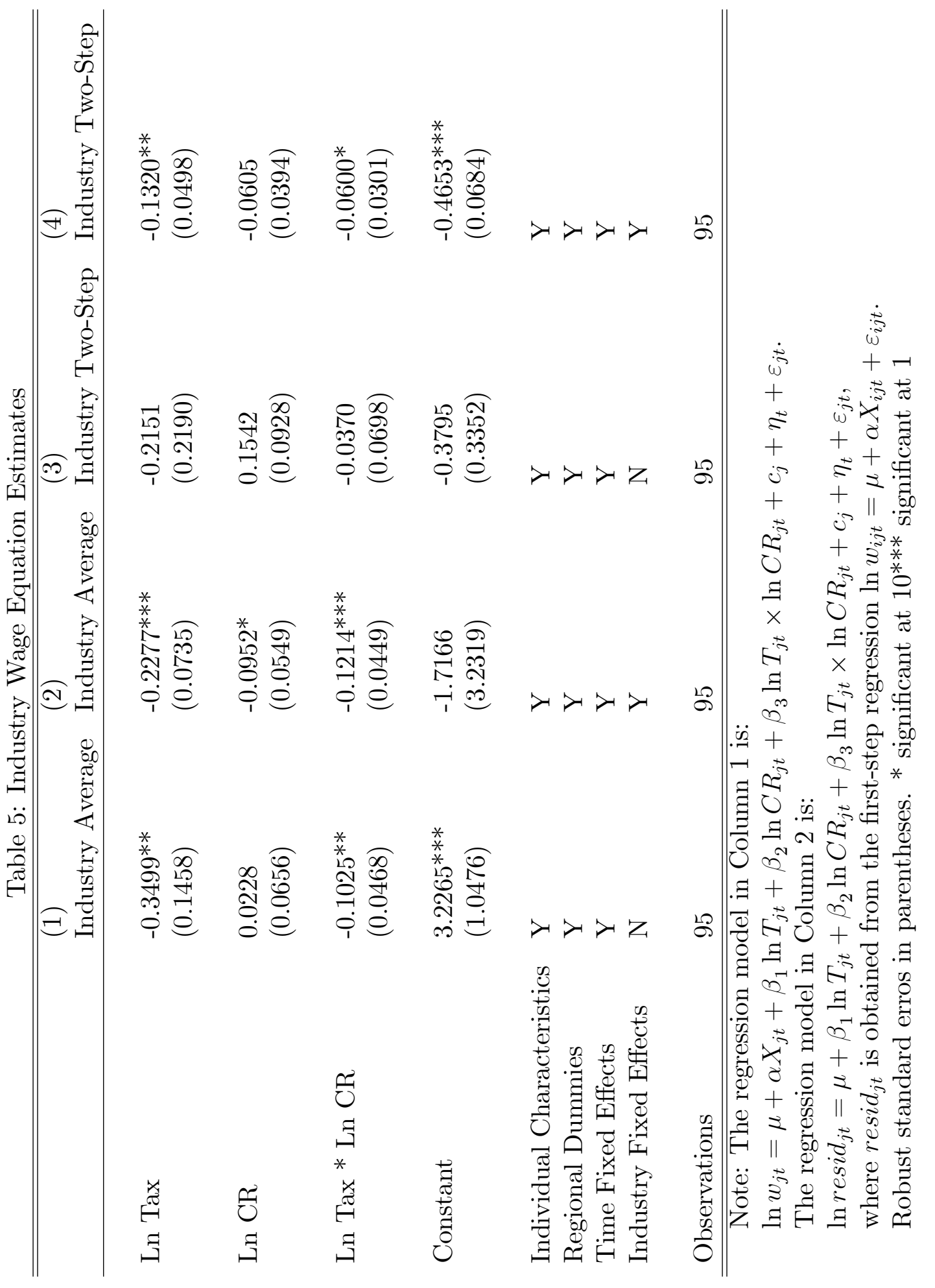


Table 6: Marginal Effects on Wages across Concentration Ratio Distribution

\begin{tabular}{|c|c|c|c|}
\hline & $\begin{array}{l}(1) \\
\text { Individual-Level }\end{array}$ & $\begin{array}{l}(2) \\
\text { Industry Average }\end{array}$ & $\begin{array}{l}(3) \\
\text { Industry Two-Step }\end{array}$ \\
\hline Mean Marginal Effect & $\begin{array}{l}-0.0283^{* * *} \\
(0.0002)\end{array}$ & $\begin{array}{l}-0.0379^{* * *} \\
(0.0091)\end{array}$ & $\begin{array}{l}-0.0382^{* * *} \\
(0.0045)\end{array}$ \\
\hline ME at CR Quartile 1 & $\begin{array}{l}0.0542^{* * *} \\
(0.0002)\end{array}$ & $\begin{array}{l}0.0736^{* * *} \\
(0.0135)\end{array}$ & $\begin{array}{l}0.0169^{* * *} \\
(0.0066)\end{array}$ \\
\hline ME at CR Quartile 2 & $\begin{array}{l}-0.0167^{* * *} \\
(0.0001)\end{array}$ & $\begin{array}{l}-0.0158^{* * *} \\
(0.0032)\end{array}$ & $\begin{array}{l}-0.0273^{* * *} \\
(0.0016)\end{array}$ \\
\hline ME at CR Quartile 3 & $\begin{array}{l}-0.0481^{* * *} \\
(0.0001)\end{array}$ & $\begin{array}{l}-0.0731^{* * *} \\
(0.0033)\end{array}$ & $\begin{array}{l}-0.0556^{* * *} \\
(0.0016)\end{array}$ \\
\hline ME at CR Quartile 4 & $\begin{array}{l}-0.1226^{* * *} \\
(0.0002)\end{array}$ & $\begin{array}{l}-0.1400^{* * *} \\
(0.0080)\end{array}$ & $\begin{array}{l}-0.0886^{* * *} \\
(0.0039)\end{array}$ \\
\hline Observations & 158925 & 96 & 96 \\
\hline
\end{tabular}

Note: The wage elasticity is calculated as the average marginal effect of ETR across the distribution of the concentration ratios. 


\section{Table A1: A Unified Industry Classification System}

\begin{tabular}{|c|c|c|}
\hline $\mathrm{UIC}$ & Industry Description & Related 87SIC \\
\hline 1 & Agricultural Production & 01,02 \\
\hline 2 & Agricultural Services, Forestry, and Fishing, Hunting and Trapping & $07,08,09$ \\
\hline 3 & Metal Mining & 10 \\
\hline 4 & Coal Mining & 12 \\
\hline 5 & Oil and Gas Extraction & 13 \\
\hline 6 & Mining and Quarrying of Nonmetallic Minerals, Except Fuels & 14 \\
\hline 7 & Construction & $15,16,17$ \\
\hline 8 & Food and Kindred Products & 20 \\
\hline 9 & Tobacco Products & 21 \\
\hline 10 & Textile Mill Products & 22 \\
\hline 11 & Apparel and Other Finished Products & 23 \\
\hline 12 & Lumber and Wood Products, Except Furniture & 24 \\
\hline 13 & Furniture and Fixtures & 25 \\
\hline 14 & Paper and Allied Products & 26 \\
\hline 15 & Printing, Publishing, and Allied Industries & 27 \\
\hline 16 & Chemicals and Allied Products & 28 \\
\hline 17 & Petroleum Refining and Related Industries & 29 \\
\hline 18 & Rubber and Miscellaneous Plastics Products & 30 \\
\hline 19 & Leather and Leather Products & 31 \\
\hline 20 & Stone, Clay, Glass, and Concrete Products & 32 \\
\hline 21 & Primary Metal Industries & 33 \\
\hline 22 & Fabricated Metal Products, Except Machinery and Transportation Equipment & 34 \\
\hline 23 & Industrial and Commercial Machinery and Computer Equipment & 35 \\
\hline 24 & Electronic and Other Electrical Equipment and Components, Except Computer & 36 \\
\hline 25 & Motor Vehicles and Motor Vehicle Equipment & 371 \\
\hline 26 & Transportation Equipment, Except Motor Vehicles & $372-6,379$ \\
\hline 27 & Measuring, Analyzing and Controlling Instruments & 38 \\
\hline 28 & Miscellaneous Manufacturing Industries & 39 \\
\hline 29 & Transportation & $40-7$ \\
\hline 30 & Communications & 48 \\
\hline 31 & Electric, Gas, and Sanitary Services & 49 \\
\hline 32 & Wholesale Trade and Retail Trade & $50,51,52-7,59$ \\
\hline 33 & Eating and Drinking Places & 58 \\
\hline 34 & Finance and Insurance & $60-4,67$ \\
\hline 35 & Real Estate & 65 \\
\hline 36 & Lodging, Personal, and Miscellaneous Repair Services & $70,72,76$ \\
\hline 37 & Business, Legal, Engineering, Accounting, Research, Management, and Related Services & $73,81,87,89$ \\
\hline 38 & Automotive Repair, Services, and Parking & 75 \\
\hline 39 & Motion Pictures & 78 \\
\hline 40 & Amusement and Recreation Services & 79 \\
\hline 41 & Health, Educational and Social Services, Museums, Galleries and Zoos, Membership Organizations & $80,82-84,86$ \\
\hline
\end{tabular}

